\title{
Modelling the Potential of Integrated Vegetation Bands (IVB) to Retain Stormwater Runoff on Steep Hillslopes of Southeast Queensland, Australia
}

\author{
Justin G. Ryan ${ }^{1, *}$, Clive A. McAlpine ${ }^{1}$, John A. Ludwig ${ }^{2}$ and John N. Callow ${ }^{3}$
}

1 Centre for Spatial Environmental Research, School of Geography, Planning and Environmental Management, The University of Queensland, St Lucia, QLD 4072, Australia;

E-Mail: c.mcalpine@uq.edu.au

2 Commonwealth Scientific and Industrial Research Organisation (CSIRO), PO Box 780, Atherton, QLD 4883, Australia; E-Mail: lasr@tpg.com.au

3 School of Earth and Environment (M004), University of Western Australia, Crawley, WA 6009, Australia; E-Mail: nik.callow@uwa.edu.au

* Author to whom correspondence should be addressed; E-Mail: justin.ryan@uq.edu.au; Tel.: +61-7-3365-7270; Fax: +61-7-3365-6899.

Academic Editor: Audrey L. Mayer

Received: 13 February 2015 / Accepted: 11 August 2015 / Published: 20 August 2015

\begin{abstract}
Rainfall intensity is predicted to increase under a changing climate, leading to increased risks of hillslope erosion, downstream sedimentation and flooding. For many catchments used for grazing and agricultural land uses, it will become increasingly important to maintain ecohydrological functioning despite climatic extremes. One means to achieve this is through strategic reforestation using locally endemic species, in spatial configurations that effectively intercept, retain or and redistribute overland flows. This paper adopts a modelling approach for investigating the potential of one such design termed "integrated vegetation bands" (IVB), to increase the retention of runoff across steep hillslopes, particularly in the sub-tropics where rainstorms are becoming increasingly intense. A spatially distributed simulation model (MIKE-SHE) was applied to a steep, grazed catchment (Maronghi Creek catchment, Southeast Queensland, Australia) to compare stormwater runoff characteristics between: (1) the existing pasture land cover; and (2) a series of hypothetical IVB added across this pasture land. The IVB were approximately $20 \mathrm{~m}$ wide, and configured at 5\% gradient towards ridgelines. Results for estimates of overland flow depth and infiltration (spatial), and accumulative water balance (temporal), confirm that
\end{abstract}


the area of hillslope retaining $>10 \mathrm{~mm} /$ day more runoff increased by $22 \%$ under IVB compared to the pasture land use. Excluding the IVB themselves, the area of hillslope where runoff retention increased was $11 \%$. During the most intense rainfall, IVB held up to $25 \%$ greater water depth and had $10 \%$ greater infiltration at the hillslope scale. At the sub-catchment scale, discharge decreased by $7 \%$ and infiltration increased by $23 \%$. The findings for sub-tropical landscapes presented here are consistent with studies conducted in temperate regions. Based on the results of this preliminary modelling work, the IVB concept has been established as a paired-catchment field trial in a high rainfall catchment in Southeast Queensland, Australia.

Keywords: vegetation bands; grazing land; stormwater runoff; water retention; ecohydrology; hillslopes; simulation modelling

\section{Introduction}

The reduction of woody and herbaceous vegetation at the hillslope scale is known to increase the volume, velocity and erosive potential of stormwater runoff [1]. Many thunderstorms in the sub-tropics can generate rainfall rates well over $100 \mathrm{~mm} / \mathrm{h}$ [2], and the frequency of severe thunderstorms with intense rainfall is projected to increase under climate change [3]. In the study area (mountainous terrain of Southeast Queensland), rainfall intensity is projected to increase by $40 \%$ by 2030 [4]. This poses a high risk of soil erosion and slope failure for this agriculturally productive region, and is likely to increase the risks of downstream sedimentation and flooding.

Native trees and shrubs modify soil structure and ground surface properties by the production of a surface litter layer, increased soil organic matter and deep root and biopore development. In native woodlands, rain infiltration rate, soil water storage capacity and soil biological activity can vary with changes in accumulated litter and soil organic matter [5,6]. While these processes occur naturally in many native ecosystems (e.g., [7,8]), they are often impaired in landscapes that support grazing and cropping land uses.

The structural form of vegetation is also important for determining the ecohydrological function it is able to perform. For example, Duran Zuazo et al. [9] found that the lowest-growing plant covers reduced runoff and soil erosion more effectively than taller sized shrubs on hillslopes of the Sierra Nevada Mountains (SE Spain). Leguedois et al. [10] found that vegetation bands (tree belts) can effectively trap sediment travelling down slope in overland flow by sedimentation processes. Blanco-Canqui et al. [11] also demonstrated that vegetative filter strips applied in cropping landscapes could reduce water velocity and increase sediment and nutrient retention. Filter strips alone, however, are unlikely to generate micro-terraces to the same degree as vegetation bands, as they are missing the woody debris component. Plant litter containing both herbaceous and woody components will form meta-stable micro-scale terraces that directly promote the emergence of backwaters.

Through its effects on soil and surface properties, perennial vegetation has the capacity to reduce surface flow velocity, enhance water infiltration and sediment retention and reduce hillslope runoff [12-14]. This suggests that by increasing the area of perennial vegetation across hillslopes, the 
negative impacts associated with extreme rainfall events may be reduced. To achieve these beneficial ecohydrological functions while at the same time minimising competitive effects, perennial vegetation can be used in banded forms that integrate with existing agricultural production (i.e., integrated vegetation bands-IVB).

Vegetation bands can buffer landscapes from intense rainfall by forming semi-permeable through-flow systems that impede and reduce the velocity of overland flows [12,13]. Leaves, bark and sticks (plant litter) along with multi-stemmed herbaceous vegetation covering the soil surface, are all efficient at intercepting water, sediment and nutrients $[14,15]$. Litter forms micro-terraces that, in turn, generate "backwaters" [16,17]. Backwaters have a particularly intriguing property-they can cause water to spread laterally across slopes [18]. This raises an interesting prospect: can IVB be configured to help spread runoff by gravity, so that water velocity is reduced while retention is increased over a greater area of the landscape?

The aim of this desktop study was to simulate how IVB affected resistance to flows down steep hillslopes, and in particular, whether water retention could be increased by passively redistributing the flows across the hillslopes. The MIKE SHE [19] hydrological model was used to simulate the effects of adding IVB to steep grazed hillslopes under intense (up to $63 \mathrm{~mm} / \mathrm{h}$ ) and prolonged rainfall conditions (five days). The IVB simulation was compared directly with the existing pasture land cover in the Maronghi Creek catchment of Southeast Queensland, Australia. The simulations were used to calculate changes in water balance and the spatial distribution of infiltration and overland flow at hillslope and sub-catchment scales. Sensitivity analyses were applied to determine each variables effect on model output. The information gained from these analyses were subsequently used to optimise the design of instrumentation in a paired catchment study that is currently underway in Southeast Queensland (ARC Linkage Project LP100100356).

\section{Method}

\subsection{Conceptual Model}

Research on vegetation that influenced the IVB concept include banded vegetation [20], litter micro-terraces [7,8], vegetation filter strips [11,21], and contour bund layouts as used by some innovative farmers $[22,23]$. The particular design applied in this study is adapted from earlier work by J.G. Ryan [24]. The IVB simulated in this study were $20 \mathrm{~m}$ wide, set at approximately $120 \mathrm{~m}$ apart, and configured to follow topography at 5\% gradient to the contour angling toward the ridgelines (Figure 1). These parameter choices for IVB are based on a compromise between the land footprint being small to minimise the competition between pasture and tress, whilst still allowing the ecohydrological benefits of the tree bands to influence catchment water balance. Other widths and gradients may offer similar functional benefits to the IVB used in this study. 


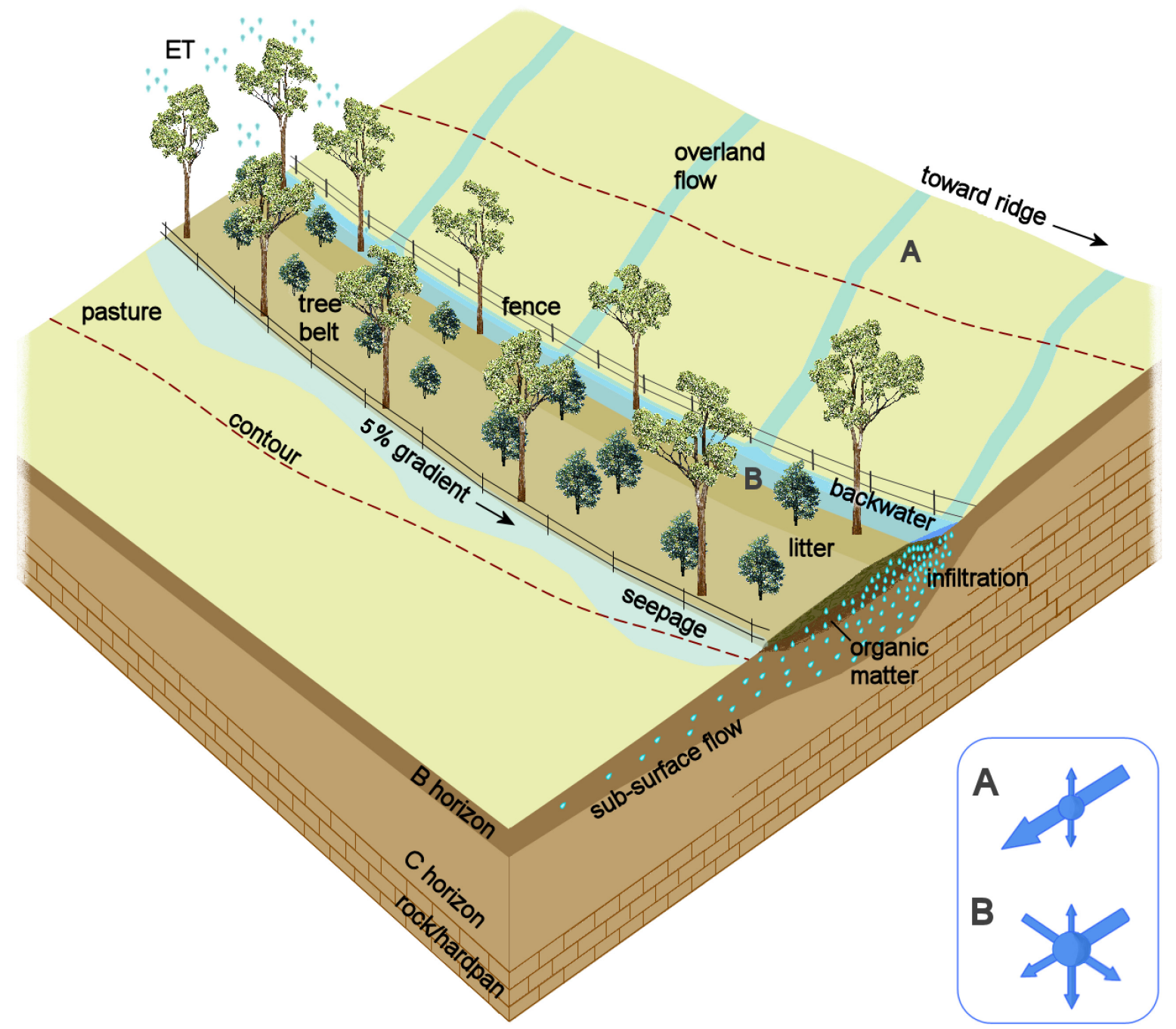

Figure 1. Conceptual model of the integrated vegetation bands (IVB) design and general ecohydrological effects. The inset shows the hypothesised difference in partitioning of overland flow on hillslopes between (A) pasture, or (B) IVB.

\subsection{Study Area}

The study area forms part of the headwaters of Maronghi Creek catchment $\left(152^{\circ} 10^{\prime} \mathrm{E},-27^{\circ} 11^{\prime} \mathrm{S}\right)$, a tributary of the Brisbane River in southeast Queensland, Australia (Figure 2). The average annual rainfall is approximately $709 \mathrm{~mm}$ based on Cressbrook Dam (6.8 $\mathrm{km}$ to the south), with about $70 \%$ falling in the summer months (October to March) as intense thunderstorms or rain depressions. The study area covers 95 ha, varies from 330 to 440 metres in elevation, and has generally steep topography with slopes up to $24 \%$. This catchment was chosen as it was devoid of native perennial vegetation cover, and contained steep grazed land on unstable soils.

The sub-catchment geology is Mesozoic to Proterozoic age igneous rocks termed the Eskdale Granitoids (Triassic), which form an extensive drainage network and steep hills containing little soil development $[25,26]$. The soils are classed as Orthic Tenosols in the Australian Soil Classification system [27], which are broadly similar to Cambisols using the world reference base (WRB) classification [28]. 
The native vegetation is grassy eucalypt woodland comprising Eucalyptus melanophloia (silver leaved ironbark), E. crebra (narrow leaved ironbark) and Corymbia erythrophloia (gum-topped bloodwood). The landscape has been largely cleared to promote grazing of native Heteropogon contortus (black speargrass) pastures. The parameters used to define the physiology of the trees within the IVB were based on these native woodlands.

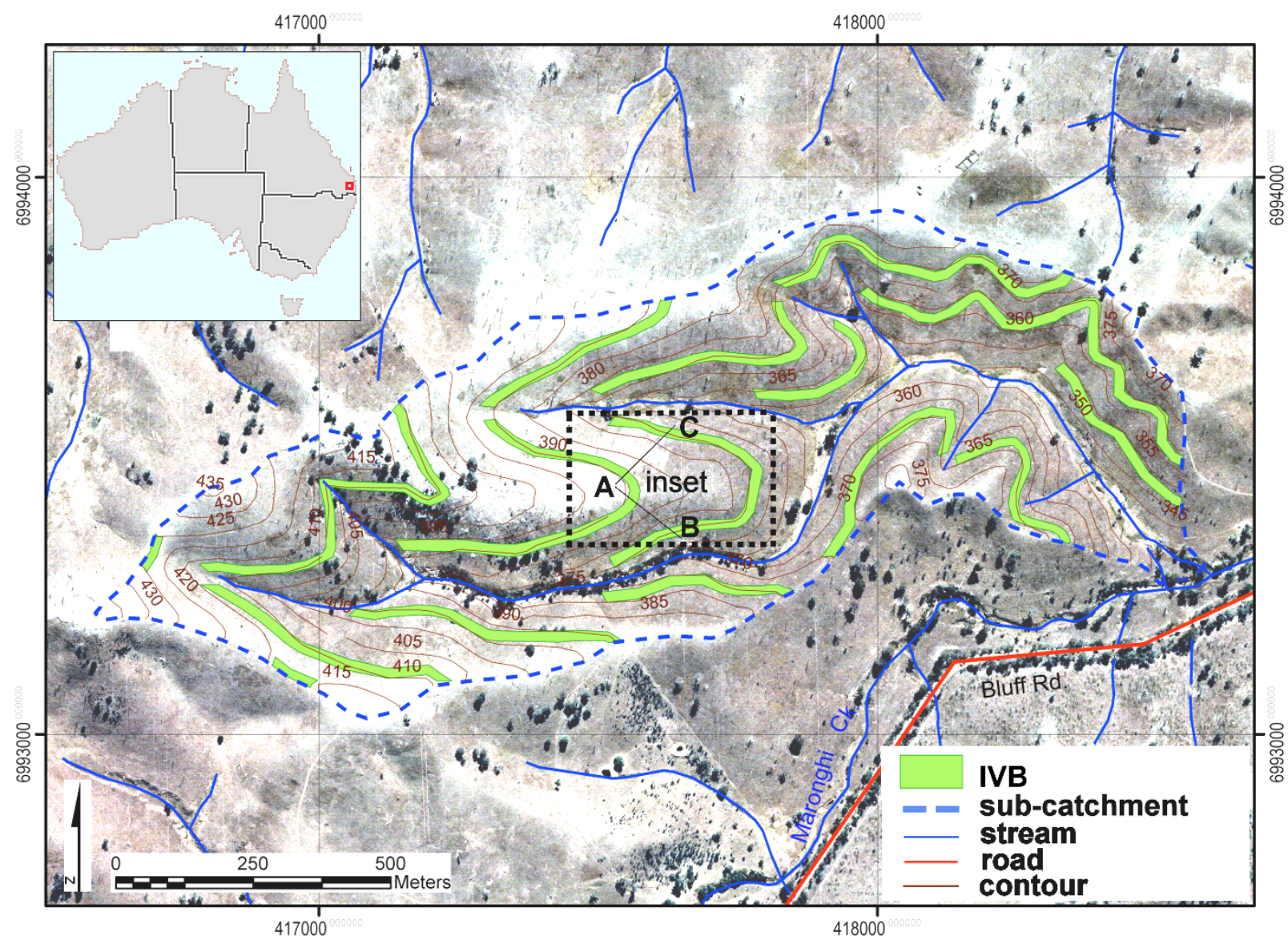

Figure 2. Location of Maronghi Creek sub-catchment showing contours, fluvial system and the existing land cover onto which IVB were applied. Note the inset which is comprised of a central ridge was selected for closer analysis of hillslope dynamics, including the two transects denoted as A-B and A-C (Coordinates are GDA 1994 MGA Zone 56).

\subsection{Software}

The water balance simulations were modelled with MIKE SHE [19], a fully distributed hydrological water balance model that accounts for spatial heterogeneity using physically based equations [29]. MIKE SHE is a part of the MIKE ZERO family of hydrological systems modelling software, as developed by the Danish Hydrological Institute (DHI). DHI's Gold Coast office (Nerang, QLD, Australia) provided the software as an in-kind contribution to the project, and the model development was assisted by their engineers. Simulations used standard MIKE SHE process sub-models for interception, evapotranspiration, overland flow, and unsaturated and saturated flow. These were finite difference for overland flow, simple 2-layer for unsaturated flow, and finite difference for saturated flow. To account for spatial variation in rooting depth and evapotranspiration, differences between pasture and IVB 
land cover types are determined in reference tables using gravity flow and Richards ET. Richards ET approximates the movement of water in the unsaturated zone of soils due to capillary and gravitational forces.

\subsection{Data Compilation and Parameter Estimates}

The Maronghi Creek catchment, like many small rural catchments, has a paucity of rainfall, runoff and stream flow data, which hinders the parameterisation of spatially explicit simulation models [30]. In such cases, parameter estimates must be derived from existing theory, prior research, on-line databases, and expert opinion from engineers and hydrologists. All these sources were used to derive parameter estimates (Table 1, [19,31-38]).

Table 1. Simulation variables and parameter estimates for two land covers.

\begin{tabular}{|c|c|c|}
\hline Variable & Pasture & IVB \\
\hline Topography & $10 \mathrm{~m} \mathrm{DEM}$ & $10 \mathrm{~m} \mathrm{DEM}$ \\
\hline Pluviograph $^{\mathrm{a}}$ & $6 \mathrm{~min}$ & $6 \min$ \\
\hline Reference evapotranspiration (mm/day) ${ }^{b, c}$ & 1.6 & 2.6 \\
\hline Reference evaporation (mm/day) ${ }^{b, c}$ & 7 & 7 \\
\hline Leaf Area Index ${ }^{b, g}$ & 0.5 & 2 \\
\hline Rooting depth $(\mathrm{m})^{\mathrm{j}}$ & 0.3 & 0.9 \\
\hline Soil depth & $0.3 *$ & 0.65 \\
\hline Soil type ${ }^{j}$ & Orthic Tenosol & Orthic Tenosol \\
\hline Infiltration rate $(\mathrm{mm} / \mathrm{h})^{\mathrm{j}}$ & 14 & 19 \\
\hline Water content (saturation) ${ }^{\mathrm{h}}$ & 0.24 & 0.38 \\
\hline Water content (field) ${ }^{\mathrm{h}}$ & 0.16 & 0.16 \\
\hline Water content (wilting) ${ }^{\mathrm{h}}$ & 0.10 & 0.10 \\
\hline Saturated hydraulic conductivity $(\mathrm{m} / \mathrm{s})^{\mathrm{f}}$ & $9.75 \times 10^{-6}$ & $9.75 \times 10^{-6}$ \\
\hline Vertical hydraulic conductivity $(\mathrm{m} / \mathrm{s})^{\mathrm{f}}$ & $1.6 \times 10^{-8}$ & $1.6 \times 10^{-8}$ \\
\hline $\begin{array}{c}\text { Surface roughness }\left(\mathrm{m}^{2}(1 / 3) / \mathrm{s}^{2}\right)^{\mathrm{d}, \mathrm{e}, \mathrm{i}} \\
\text { (Manning's } \mathrm{M})\end{array}$ & 12.5 & 2.5 \\
\hline Detention storage (mm) & 3 & 8 \\
\hline Specific yield $(\mathrm{mm})^{\mathrm{f}}$ & 0.2 & 0.2 \\
\hline Specific storage $(\mathrm{mm})^{\mathrm{f}}$ & 0.02 & 0.02 \\
\hline
\end{tabular}

In the study area, Eskdale Granitoids weather to kaolinite and illite clays and albite [25]. Soils are slightly acidic ( $\mathrm{pH}$ 6.0-6.5), shallow to moderately deep, very dark grey to brown, structure-less "Earthy Sands" [39], that occur between granodiorite rock outcrops, and are often underlain by impermeable sub-soils (shallow clay hardpan and rocks) [40]. These clays are relatively stable to erosion but have poor retention of water and cations [41].

Soil parameter were derived from the "ASRIS" database [36,38]. Based on the relationship between maximum volumetric water content at saturation equalling total soil pore volume, bulk density values for the surface soil $\left(1525 \mathrm{~g} / \mathrm{m}^{3}\right)$ and sub-soil $\left(1733 \mathrm{~g} / \mathrm{m}^{3}\right)$ were converted to soil saturated water content (SAT) values of 0.43 and 0.35 , respectively. Sivapalan [42] reported SAT at 0.42 for an Orthic 
Tenosol in a cropping landscape in south-eastern Australia (a more temperate climate than the study area), but given the influences of steep terrain, soil compaction from loss of biopores and organic matter, SAT for IVB was set at 0.38 and the grazed open pastures at 0.24 .

Saturated hydraulic conductivity $\left(K_{s}\right)$ of the surface soil was $14 \mathrm{~mm} / \mathrm{h}$ (pasture) and $19 \mathrm{~mm} / \mathrm{h}$ (IVB), while the saturated zone horizontal and vertical hydraulic conductivities set to $9.75 \times 10^{-6} \mathrm{~m} / \mathrm{s}$ and $1.6 \times 10^{-8} \mathrm{~m} / \mathrm{s}$ respectively. These values are consistent with the association of Tenosols with high drainage and low runoff [43]. Soil depth was set at $300 \mathrm{~mm}$ (pasture) and $650 \mathrm{~mm}$ (IVB) to account for differences in compaction and erosion of soil under the pressure of grazing compared to deeper profiles that form in native woodlands under the influence surface plant litter and deep tree roots/biopores.

Surface roughness variability across the hillslopes was represented by a spatial grid containing Manning's $M$ values, also known as "Strickler's value" (Manning's $M$ is the inverse of the more conventional Manning's $n$ ). For example, values of $n$ of 0.01 (smooth channel) and 0.10 (thickly vegetated channel) correspond to $M$ values of 100 and 10 [19]. Overland flow across hillslopes often reflect much coarser surface roughness than for channels. To reflect this, the $M$ value for pastures was 12.5 [34], and 2.5 for IVB based on the added surface roughness of fallen timber and plant litter under trees [37]. These are similar values to those published for other woodlands (e.g., [44]).

Estimates for detention storage $(D S)$ can vary considerably [45], from $5 \mathrm{~mm}$ for bare sandy soils and up to $32 \mathrm{~mm}$ for some native forests [46]. For a sub-humid, semi-arid Eucalypt woodland in northern Queensland, Bonell and Williams [47] estimated $D S$ at $3.6 \mathrm{~m}( \pm 1.6 \mathrm{~mm})$, whereas Yirdaw and Luukkanen [48] estimated plant litter depths at 5 to $6 \mathrm{~mm}$ for young plantation eucalypts. To reflect the contrasting effects of grazing and litter build up under mature eucalypt woodlands in a sub-tropical environment, we used $D S$ values of $3 \mathrm{~mm}$ for pasture and $8 \mathrm{~mm}$ for IVB.

Physiological differences between grasses and trees, including leaf area index (LAI) [32], rooting depth and evapotranspiration, were included in the model despite the short simulation time (one week). Evapotranspiration was $1.60 \mathrm{~mm} /$ day for pasture and $2.60 \mathrm{~mm} /$ day for IVB, which equates to approximately $949 \mathrm{~mm} / \mathrm{yr}$, similar to the $2.61 \mathrm{~mm} /$ day $(953 \mathrm{~mm} / \mathrm{yr})$ estimate stated by Gordon et al. [49] for average annual evapotranspiration in open eucalypt forests in Australia. Potential evapotranspiration (PET) [33] was based on the long-term average from Cressbrook Dam of $1505 \mathrm{~mm} / \mathrm{yr}$ or $4.12 \mathrm{~mm} / \mathrm{day}$.

This study focused on modelling a representative extreme rainfall event following a dry period. The modelled rainfall event was derived from a six minute pluviograph record collected at the Cressbrook Dam weather station [50] between the 6 and 12 February 1999 (Figure 3). Although more recent heavier rainfall events have occurred in this area (e.g., January 2010), this event was selected as being "representative" of a dry period where soils may have low ground cover that are subsequently exposed to heavy rainfall and gradually become more saturated over several days. Most of the rain fell between the 7 and 11 February ( $276 \mathrm{~mm}$ in total), with a maximum six minute rainfall intensity of $61 \mathrm{~mm} / \mathrm{h}$. The average recurrence interval (ARI) for this event was 1:20 years, with a six-minute time-step used for the model due to the extreme variability in rainfall rates that can occur over short timeframes [51].

A $10 \mathrm{~m}$ DEM was derived from $5 \mathrm{~m}$ contour data and overlain on a rectified 1:5000 orthophoto of the study area to check for spatial consistency. False sinks were identified manually, and eliminated using a post-processing fill operation to provide a hydrologically realistic surface. All spatial data were based on a grid-based or raster GIS format created in ArcGIS 9.1 at $10 \mathrm{~m}$ resolution. The existing land cover was mapped from the orthophoto, with IVB added through on-screen digitizing in ArcGIS. 
Parameters (as defined above) were set as benchmarks from which sensitivity analyses were performed. Multiple simulations runs were conducted, in which each benchmark estimate was incrementally varied to higher or lower values. Simulated outputs of evapotranspiration (ET), infiltration $(I N F)$ and boundary outflow $(Q)$ were compared for each set of parameter estimates and entered into MIKE SHE based on their mean and standard deviation.

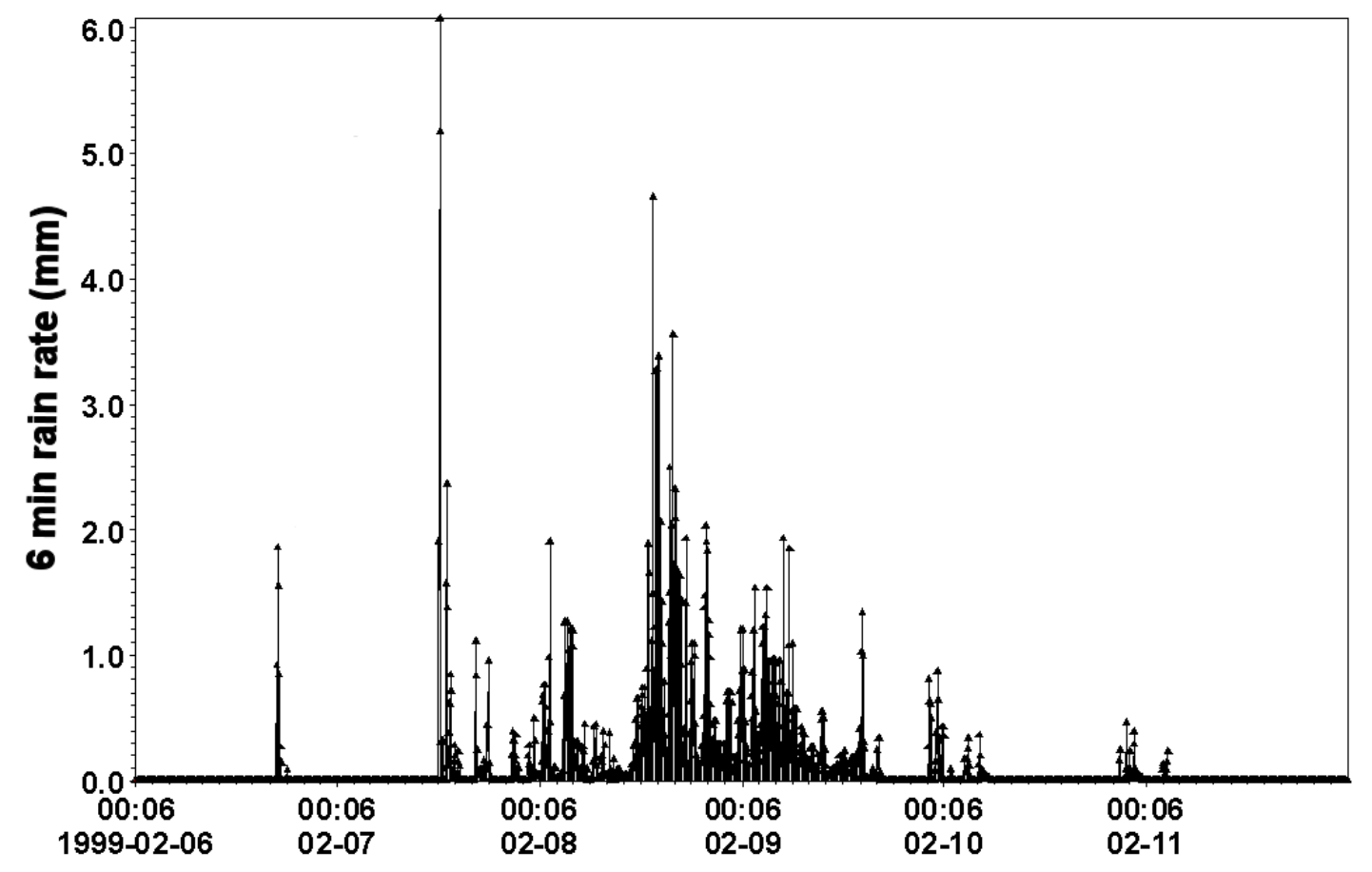

Figure 3. Plot showing the six minute rainfall pluviograph between 12:06 AM 6 February and 12:00 AM 12 February 1999 at Cressbrook Dam, Queensland, Australia (source: BOM 1999).

\section{Results}

\subsection{Spatial Distribution of Overland Flow and Infiltration}

\subsubsection{Hillslope Scale}

Two hillslope profiles were taken from either side of a central ridge within the catchment to compare the response of overland flow $(O F)$, and its distribution (depth) for pastures $(\mathrm{P})$ and IVB (Figure 4a,b). These profiles correspond to transects A-B and A-C in Figure 2. The two profiles begin at a common point (A), and are orientated down the steepest gradient to points $\mathrm{B}$ and $\mathrm{C}$ respectively. Two time-steps are shown in each profile, one time-step (TS362) during a very heavy rain period at the beginning of the simulation, the other time-step (TS639) when the catchments soils were fully saturated. At TS362 for the pasture land cover, $O F$ depth was $6 \mathrm{~mm}$ and $6 \mathrm{~mm}$ for transect A-B and $6 \mathrm{~mm}$ and $7 \mathrm{~mm}$ for A-C. Under IVB at TS362, OF depth was $16 \mathrm{~mm}$ and $14 \mathrm{~mm}$ in transect A-B and $14 \mathrm{~mm}$ and $14 \mathrm{~mm}$ in A-C. This represents up to a 266\% increase in $O F$ depth for transect A-B and $200 \%$ for A-C under IVB compared to the pasture land cover at the corresponding time and location. Under saturated conditions (TS639), the pasture $O F$ depth was $6 \mathrm{~mm}$ and $7 \mathrm{~mm}$ (A-B) and $7 \mathrm{~mm}$ and 
$8 \mathrm{~mm}$ (A-C), whereas IVB held $20 \mathrm{~mm}$ and $19 \mathrm{~mm}(\mathrm{~A}-\mathrm{B})$ and $18 \mathrm{~mm}$ and $19 \mathrm{~mm}$ (A-C). These values show IVB holding up to $286 \%$ greater $O F$ depth in transect A-B and $238 \%$ in A-C when soils are saturated.

Close observation of Figure $4 \mathrm{~b}$ (transect A-C) also highlights an interesting shift in the location of the peak in $O F$ depth where it interacts with the IVB. During the period of heavy rainfall (TS362), $O F$ is at its deepest at the top edge of the IVB which indicates a backwater has formed, whereas during the saturated conditions (TS639), OF is deeper within the IVB themselves, suggesting the extra surface roughness of the IVB (i.e., plant litter) helps to hold more $O F$ at such times. In addition, during the heavy rainfall period where the backwater formed before the IVB, OF depth concurrently decreased immediately down-slope $(5 \mathrm{~mm})$ of the IVB compared to the corresponding location in the pasture land cover $(7 \mathrm{~mm})$.
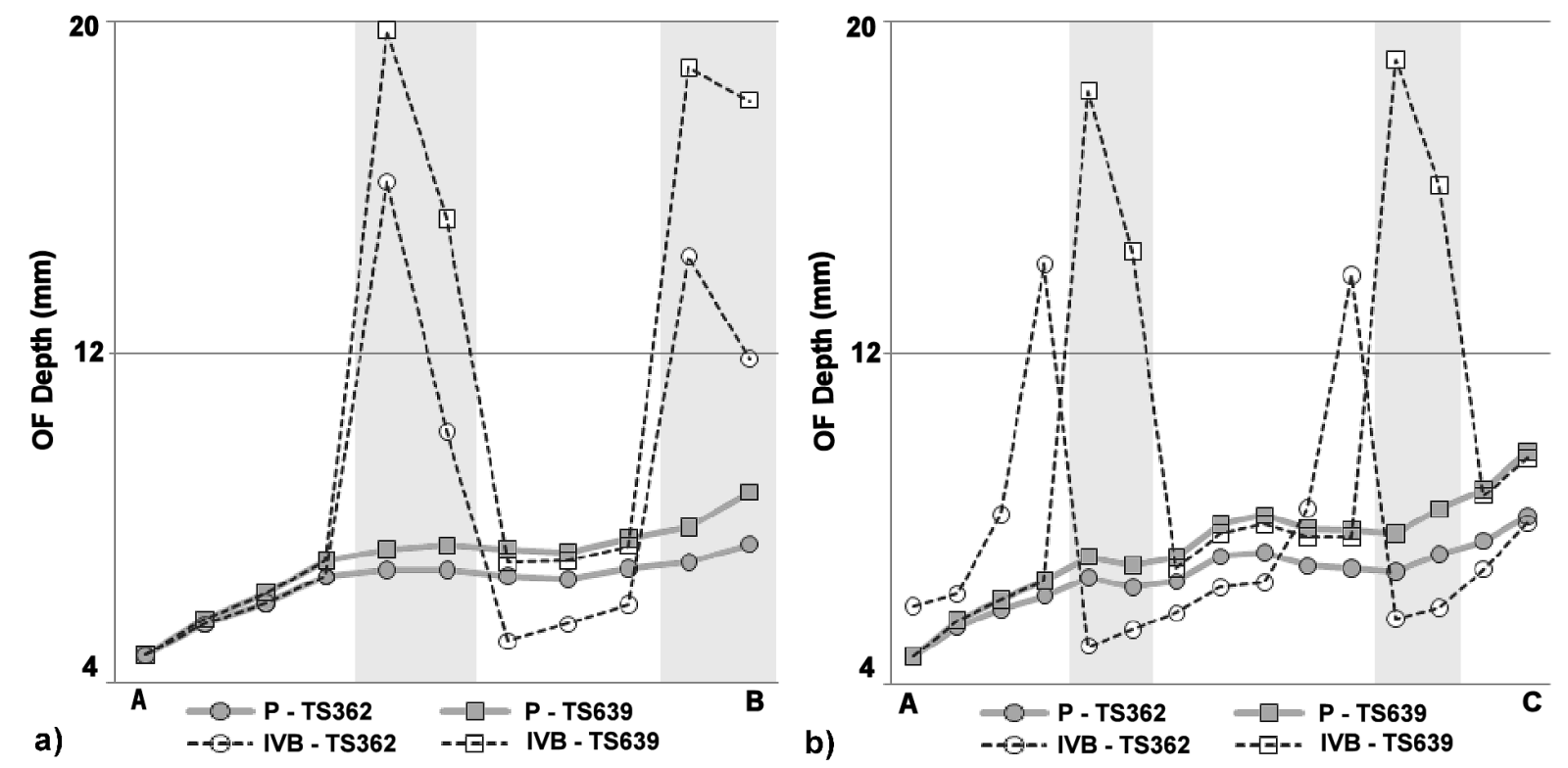

Figure 4. Two hillslope profiles showing overland flow $(O F)$ depth for two transects A-B (a) and A-C (b) at two time-steps (T362 and T639). The two transects start at a common cell (A) located on a central ridge of the sub-catchment (see Figure 2), with the trajectory of each at right angles down the steepest gradient to points B and C. TS362 was at the beginning of the first thunderstorm event when the soil was dry (12:15 PM 7 February 1999), whereas TS639 was taken when the catchment was saturated (4.15 PM 8 February 1999). The location of IVB along the transects are displayed as shaded bars. The most obvious indicator is the much greater depth of overland flow before and within the IVB, and the slight decrease in depth immediately down-slope. This indicates increased water retention in the IVB.

Flow directions and velocity results show that during the maximum rain rate on the same section of the main ridgeline (Figure 5), water depth was reduced downslope of the IVB but slightly increased in the backwaters before the bands. The direction of the vectors also moved towards the ridge at these locations, increasing slightly in velocity before the IVB and then decreasing within the bands themselves. This supports the conceptual model of IVB functioning-runoff creates backwaters behind 
vegetation bands, which in turn, moves runoff laterally across the hillslope. These modifications to runoff resulted in $O F$ depth on the main ridge (Figure 2, inset) being $+28 \%\left(0.009 \mathrm{~m}\right.$, S.E. $\left.1.46 \times 10^{-4}\right)$ in IVB simulations compared to pasture $\left(0.007 \mathrm{~m}\right.$, S.E. $\left.5.01 \times 10^{-5}\right)$, which was significantly different $(p<0.0001, n=896)$.
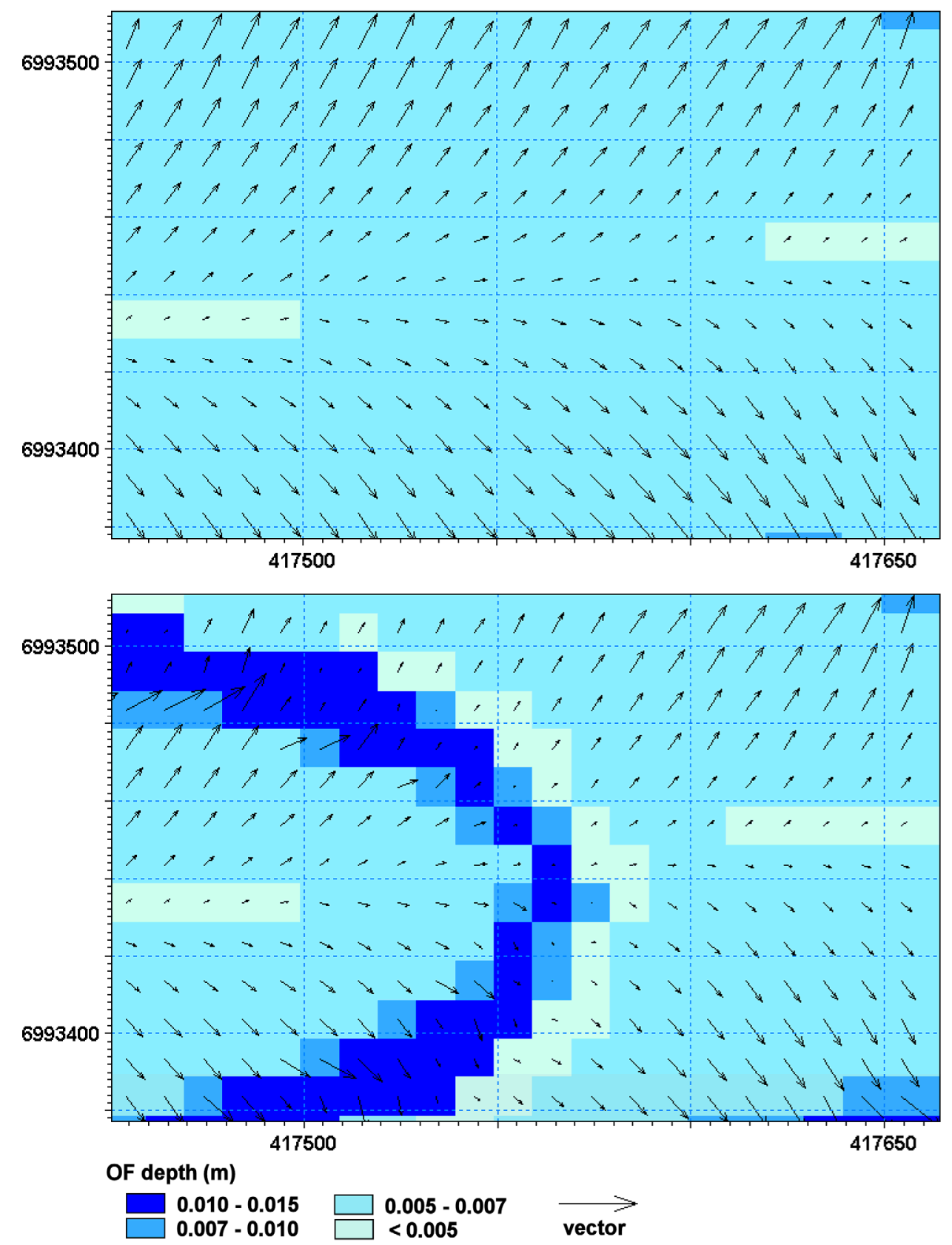

Figure 5. Raster model showing $O F$ distribution between pasture (top) and IVB (bottom) simulations. The direction and velocity are related to vector orientation and length respectively. Note the significant reduction in overland flow depth beneath the IVB, and the slight redistribution toward the central ridge compared to the pasture simulation.

Changes in mean infiltration rates and distribution were also evident. Based on a time-step when rainfall was at its most intense and the soils reasonably dry, the difference between IVB and pasture land covers was clear (Figure 6). During this period, infiltration was $7 \%$ and $10 \%$ greater at the 
sub-catchment and hillslope scales respectively. Infiltration slightly increased above the IVB in the backwater area, significantly increased directly beneath them, and slightly decreased immediately down slope of them. Considering the spatial extent of grid cells where both overland flow depth and infiltration were modified, it was apparent that the area of hillslopes retaining $>10 \mathrm{~mm} /$ day more runoff increased by $22 \%$ under IVB compared to the pasture land use. Given that the IVB covered an area equal to $11 \%$ of the catchment area, this reflects an increase of $11 \%$ in the area where runoff was retained outside of the IVB themselves.

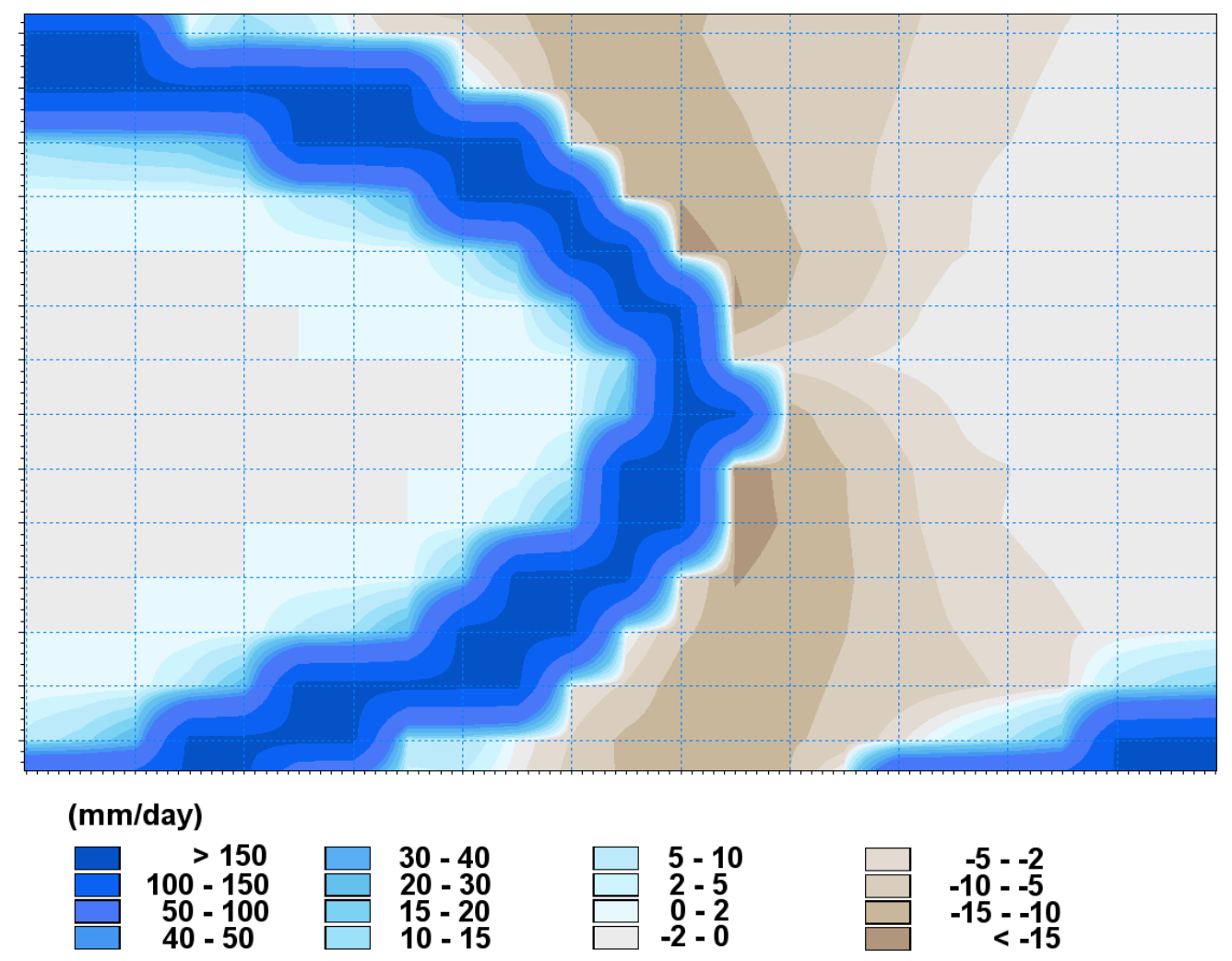

Figure 6. Raster model showing change in mean infiltration ( $\mathrm{mm} /$ day) under IVB (NB: the location is the same as Figure 5).

\subsubsection{Sub-Catchment Scale}

At the scale of the sub-catchment, a grid based time-series of maximum depth in overland flow $(O F)$ illustrates a greater water depth under IVB than for pasture, but little difference in water depth in the channels (Figure 7). The time-series were based on $24 \mathrm{~h}$ time-steps beginning 12:06 pm 7 February and ending 12:00 pm 11 February 1999. One exception to these results: the extent of saturation on footslope areas was less in the IVB simulations.

Changes to overland flow depth recorded during the rainfall event showed significant variability through time, as well as between hillslope and sub-catchment scales (Table 2). Mean and maximum overland flow depths were greater in the IVB at the hillslope scale, although at the sub-catchment scale this trend was mostly absent. This implies that the greater water depth under the IVB was temporary during heavy rainfall, and after infiltration across the hillslopes, discharge at the sub-catchment scale was lower. However, towards the end of the simulation after rainfall had ceased, the IVB contributed 
to a slight increase in water depth in the channel compared to the pasture land cover. This had the effect of slightly extending the temporal period of baseflows within the stream.
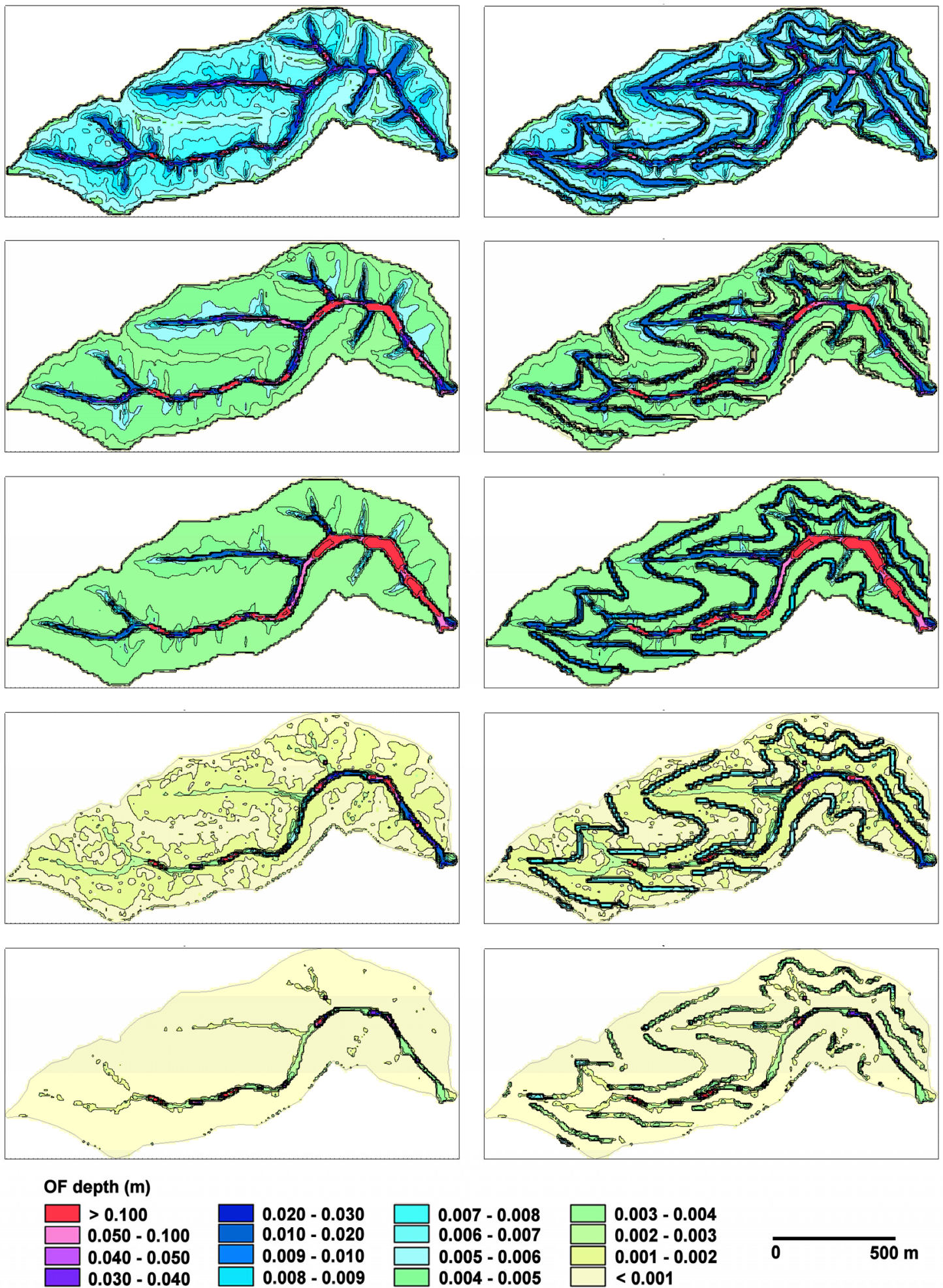

Figure 7. A time-series $O F$ for pasture (left) and IVB (right) models. The time-steps are in series from top to bottom showing changes in overland flow every $24 \mathrm{~h}$ beginning at 4:15 pm 7 February 1999. The major changes are increased flow depth in IVB themselves, as well as a broader spatial distribution and longer duration of flow in the IVB model. 
Table 2. Summary of overland flow depth $(O F)(\mathrm{m})$.

\begin{tabular}{cccccccc}
\hline & & \multicolumn{3}{c}{${\text { Mean }\left(\boldsymbol{O} \boldsymbol{F}_{\boldsymbol{\mu}}\right)}^{-}$} & \multicolumn{3}{c}{ Max $\left(\boldsymbol{O} \boldsymbol{F}_{\mathbf{m a x}}\right)$} \\
\hline Area & Day & Pasture & IVB & $\boldsymbol{\Delta} \%$ & Pasture & IVB & $\boldsymbol{\Delta} \%$ \\
\hline \multirow{3}{*}{ sub-catchment } & 1 & 0.008 & 0.008 & -2 & 0.370 & 0.257 & -31 \\
& 2 & 0.010 & 0.007 & -28 & 0.672 & 0.517 & -23 \\
& 3 & 0.023 & 0.024 & +2 & 1.809 & 1.774 & -2 \\
& 4 & 0.002 & 0.002 & -64 & 0.216 & 0.216 & +0.2 \\
& 5 & $<0.001$ & $<0.001$ & +60 & 0.212 & 0.212 & 0 \\
\hline \multirow{3}{*}{ hillslope (subset) } & 1 & 0.007 & 0.007 & +12 & 0.012 & 0.020 & +64 \\
& 2 & 0.004 & 0.004 & -2 & 0.007 & 0.013 & +101 \\
& 3 & 0.004 & 0.005 & +28 & 0.005 & 0.011 & +121 \\
& 4 & 0.001 & 0.002 & +94 & 0.002 & 0.007 & +246 \\
& 5 & $<0.001$ & $<0.001$ & $*$ & 0.001 & 0.005 & +287 \\
\hline
\end{tabular}

Notes: in this series day 1 begins at 12:00 pm 7 February 1999, and each day thereafter is taken at 12:00 pm.

* denotes change is negligible.

\subsection{Model Water Balance Predictions}

The greatest changes in water balance between the pasture and IVB simulations at the sub-catchment scale were $23 \%$ greater maximum infiltration $(I N F)(54$ to $66 \mathrm{~mm})$ and $7 \%$ lower maximum boundary outflow $(Q)$ (211 to $196 \mathrm{~mm}$ ) (Table 3). Mean values were also significant for these two estimates, whereas the remaining water balance relationships showed only minor statistical differences. The main reason behind the small differences overall is that IVB cover only a small footprint of land, with pasture land cover dominant in both simulations.

Table 3. Summary of water balances for pasture and IVB simulations (mm). $S Z=$ saturated zone; $O F=$ overland flow; $Q=$ discharge (boundary outflow).

\begin{tabular}{ccccccccc}
\hline & \multicolumn{4}{c}{ Pasture } & \multicolumn{5}{c}{ IVB } \\
\hline Variable & Min & Max & Mean & S.E. & Min & Max & Mean & S.E. \\
\hline Net Precipitation & & 276 & & & & 276 & & \\
Evaporation & 0 & 23 & 8 & 0.22 & 0 & 23 & 8 & 0.22 \\
Infiltration & 0 & 54 & 38 & 0.57 & 0 & 66 & 46 & 0.71 \\
SZ- $>$ OF & -5 & 0 & -2 & 0.04 & -5 & 0 & -2 & 0.04 \\
OF- $>S Z$ & 0 & 2 & 1 & 0.02 & 0 & 2 & 1 & 0.02 \\
$Q$ & 0 & 211 & 98 & 2.55 & 0 & 197 & 90 & 2.39 \\
OF Stor.Change & 0 & 42 & 8 & 0.34 & 0 & 42 & 8 & 0.34 \\
Error & -33 & 10 & -0.2 & 0.30 & -30 & 9 & -0.3 & 0.27 \\
\hline
\end{tabular}

\subsection{Model Sensitivity Analysis}

\subsubsection{Soil Water Content at Saturation (SAT)}

Changes in estimates of soil water content at saturation (SAT) had a significant bearing on simulated water balance outputs (Figure 8a). As SAT increased INF also increased, whereas $Q$ decreased. Variability in water balance outputs for the pasture land cover was much greater $(E T \sigma 1.34 ; I N F \sigma$ 
29.33; $Q \sigma 34.87)$ than for comparable IVB simulation runs (ET $\sigma 0.05 ; I N F \sigma 5.71 ; Q \sigma 6.79)$. This implies that SAT has a major bearing on the retention of runoff on hillslopes when it decreases through land use management (i.e., grazing on steep slopes).
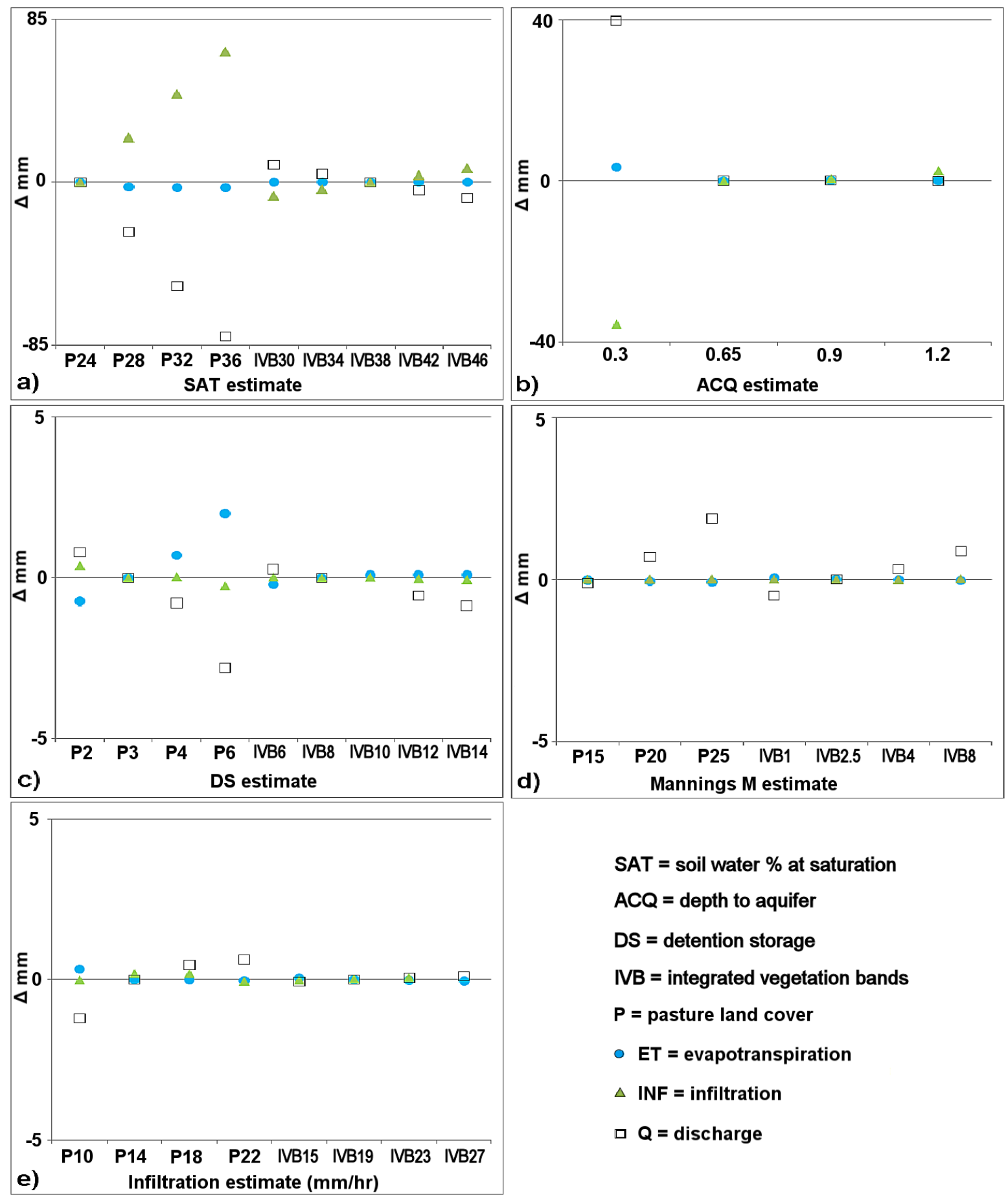

SAT = soil water $\%$ at saturation

$A C Q=$ depth to aquifer

DS = detention storage

IVB = integrated vegetation bands

$P=$ pasture land cover

- $E T$ = evapotranspiration

$\triangle \mathrm{INF}=$ infiltration

ㅁ $\mathbf{Q}=$ discharge

Figure 8. Scatter plots showing the difference $(\mathrm{mm})$ between pasture and IVB simulation models in terms of evapotranspiration $(E T)$, infiltration $(I N F)$ and boundary outflow $(Q)$ water balance estimates. Five parameters had varying degrees of influence on water balance estimates, in order of significance these were: (a) soil water content at saturation $(S A T)$; (b) depth to an impermeable layer $(A C Q)$; (c) detention storage $(D S)$; (d) surface roughness $(M)$; and (e) infiltration rate $\left(K_{S}\right)$. 


\subsubsection{Soil Depth (ACQ)}

In the MIKE SHE model, soil depth was limited by the depth to an impermeable layer or aquifer (ACQ). Varying the depth to this layer had a significant effect on model outputs when less than $0.3 \mathrm{~m}$, otherwise it had little effect (Figure 8b). This is evident in the standard deviation across all depths (ET $\sigma 1.68 ; I N F \sigma 18.26 ; Q \sigma 19.86$ ) compared to the standard deviation when the $0.3 \mathrm{~m}$ depth was excluded (ET $\sigma 0.06 ; I N F \sigma 1.35 ; Q \sigma 0.04)$. The most noticeable effect when depth was at $0.3 \mathrm{~m}$ was a higher estimate of $Q(40 \mathrm{~mm})$, whereas $I N F$ was reduced by a similar margin $(-35 \mathrm{~mm})$. There was little change in ET for any depth.

\subsubsection{Detention Storage (DS)}

Detention storage had a moderate effect on $E T, I N F$, and $Q$ (Figure 8c). Increasing the estimate of detention storage slightly increased $E T$ and slightly decreased $Q$, with little effect on $I N F$. The total variation in water balance estimates across both pasture and IVB model runs combined was low $(E T \sigma 0.76$; INF $\sigma 0.16 ; Q \sigma 1.02)$. Estimates varied more in pasture simulation runs $(\sigma E T 1.16$; $I N F \sigma 0.25 ; Q \sigma 1.54)$ than in IVB simulation runs ( $\sigma E T 0.13 ; I N F \sigma 0.03 ; Q \sigma 0.45)$. This implies that detention storage is a short-term process, important during and for a short time after rainfall occurs, after which the detained store of water evaporates or infiltrates.

\subsubsection{Surface Roughness (M)}

Modifying estimates of surface roughness $(M)$ had a slight effect on $Q$ (Figure $8 \mathrm{~d}$ ). As estimates of $M$ were increased (i.e., less rough) water balance outputs indicated that $Q$ increased, with little change in ET or INF. This was evident in the standard deviation $(\sigma)$ of ET across all estimates (ET $\sigma 0.04$; $I N F \sigma 0.01 ; Q \sigma 0.79)$. Variability in water balance estimates were again greater for pasture simulation runs $(\sigma E T 0.05 ; I N F \sigma 0.003 ; Q \sigma 1.05)$ than for IVB simulation runs ( $\sigma E T 0.01 ; I N F \sigma 0.02 ; Q \sigma 0.44)$.

\subsubsection{Hydraulic Conductivity of Surface Soil $\left(\mathrm{K}_{\mathrm{s}}\right)$}

Varying estimates for infiltration rate in the surface soil layer $\left(K_{s}\right)$ had only a slight effect on $Q$, and a small effect on $I N F$ or ET (Figure 8e). The reason behind the small effect on infiltration is that soils were saturated and unable to "infiltrate" more water. Including estimates from both pasture and IVB simulation runs combined, the variation in outputs were minimal (ET $\sigma 0.13 ; I N F \sigma 0.14 ; Q \sigma 0.55$ ). Model outputs for the pasture land cover $(\sigma E T 0.18 ; I N F \sigma 0.21 ; Q \sigma 0.83)$ varied more than for vegetation bands simulation runs $(\sigma E T 0.04 ; I N F \sigma 0.05 ; Q \sigma 0.07)$.

\section{Discussion}

\subsection{Major Findings and Comparisons to Other Vegetation Systems}

The simulations and sensitivity analyses indicate that changes to soil water holding capacity and soil depth are the major drivers of increased water retention in IVB compared to pasturelands without bands. Other surface related factors such as detention storage, surface roughness and rain infiltration 
rate have a slight effect on water retention individually, whereas their combined effect does have a noticeable effect on overland flow distribution and longevity of discharge in the stream.

Water flow was detained at greater depths in the IVB, causing water to spread and infiltrate across the slope. The actual area of hillslope where more than $10 \mathrm{~mm}$ of runoff was retained was increased by $22 \%$ in IVB compared to the pasture land cover, or an $11 \%$ increase of the hillslope area outside of the land footprint of IVB themselves. The extra water stored in IVB also contributed to a slight lengthening of base flow in the main drainage line. This suggests that where IVB are applied over a much larger area (many properties), some extension of base flow duration in ephemeral streams may occur. The results also show that peak discharge is lower under IVB, which may also reduce the potential for damage to the downstream fluvial network following heavy rainstorms.

The results are consistent with known effects of vegetation on catchment hydrology. For example, catchments with native cover of woody perennials often have greater water retention than for comparable, but deforested, catchments [52]. Planted bands of perennial vegetation (tree belts) were also found by Ellis et al. $[16,53]$ to retain significant runoff under moderate rainfall rates in a temperate agricultural landscape of southern Australia. Using a field based rainfall simulator situated on a Red Chromosol (duplex) soil of $12 \%$ slope, they found that tree belts could intercept $100 \%$ of runoff at rainfall intensities of $45 \mathrm{~mm} / \mathrm{h}$ over 13 minutes duration, $50 \%$ at $45 \mathrm{~mm} / \mathrm{h}$ over 30 minutes duration, but became breached by runoff at $75 \mathrm{~mm} / \mathrm{h}$ over 30 minutes duration.

The spatial configuration of IVB applied in this study had a direct effect on runoff retention and distribution. Other research has also shown this for grazed semi-arid landscapes. For example, Bartley et al. [54] found hillslopes of the semi-arid Burdekin River catchment in northern Queensland, Australia, had up to nine times more runoff and 60 times more sediment loss under a heterogeneous mix of vegetation cover and bare ground compared to hillslopes with the same mean vegetation cover but no large bare soil patches. Similarly, Boer and Puigdefabregas [6] found that water and sediment yields from hillslopes in semi-arid SE Spain, were greater when vegetation was heterogeneously distributed compared to hillslopes with more uniform distributions. In semi-arid regions, patches, bands or isolated clumps form naturally depending on runoff and run-on characteristics [55]. In semi-arid regions of Australia, banded vegetation patterns have been suggested to capture up to $8 \%$ more runoff than other vegetation patterns [55].

The orientation of the IVB modelled in this study helped to retain runoff and spread water more than the homogenous pasture land cover. Infiltration was directly affected, with slightly more infiltration directly beneath and upslope of the IVB and slightly less down slope of the bands themselves. The upslope increase is indicative of the effects of backwaters forming due to resistance to runoff created by the IVB.

\subsection{Model Performance}

The sensitivity analyses indicated that water balance outputs were most sensitive to incremental changes in parameters related to soil water holding capacity at saturation and soil depth. Other parameters that had an influence on model outputs, but to a lesser degree, were detention storage, surface roughness and infiltration rate. These variables had more effect on runoff distribution. The responses of the model to changes in parameters provide a valuable indicator of the causal effects 
instigated by IVB, which help to optimise the monitoring program for the full field-trial. The remaining parameters had little effect on model outputs and are not reported on here.

\subsubsection{Saturated Soil Water Content (SAT)}

Modifying estimates of soil water content at saturation (SAT) had a noticeable influence on water balance outputs. In general, higher estimates of $S A T$ resulted in greater infiltration (INF) and decreased discharge $(Q)$. In a study on steep semi-arid hillslopes of the Tigra region, Ethiopia, Descheemaeker et al. [56] found that water holding capacity, saturated hydraulic conductivity and bulk density were parameters that affected the volume of runoff. More specific to SAT estimates within MIKE SHE, Christiaens and Feyen [57] also found that their model was sensitive soil water content. Similarly, Oliver and Smettem [58] found that SAT and the soil water retention curve for a "sandy soil" had a significant effect on their modelling output.

\subsubsection{Depth to Impermeable Layer (ACQ)}

Soil depth (depth to hardpan) had a noticeable effect on water balance outputs. Scherrer et al. [59] consider that estimates of the depth to the impervious layer can greatly affect the potential storage volume of the soil, and in turn, determine how much water is needed to saturate the soil. However, Sahoo et al. [60] found drainage depth had little effect on MIKE SHE outputs in their modelling of a steep, high rainfall Hawaiian catchment. Over longer simulation periods the depth to an impermeable layer or aquifer may become more important because impermeable layers can limit rooting depth [61]. Limits to rooting depth, in turn, can modify both surface and sub-surface lateral flow characteristics [62]. This suggests that longer simulation periods would be needed to quantify how tree root and biopore development modify soil depth, depth to an impermeable layer or aquifer, and possible effects on hydraulic conductivity of the saturated zone.

\subsubsection{Detention Storage}

Variations to detention storage estimates had a less noticeable effect on model outputs. The increased detention storage under IVB slightly increased $E T$ whereas $Q$ slightly decreased, with little effect on INF. The surface detention storage estimates defined in MIKE SHE are representative of the development of a litter layer beneath IVB. This increase of detention storage reflects additional moisture trapped behind layers or micro-terraces of litter, which may then be available for infiltration. Guevara-Escobar et al. [63] found that the maximum storage capacity of litter from Populus nigra increased as rainfall intensity increased. These authors also cited work from Huber and Oyarzun [64] who found litter intercepted up to $8.9 \%$ of annual rainfall in a native evergreen forest in Chile, whereas the study of Balazs [65] found the litter of Larix decidua intercepted up to $18 \%$ of rainfall.

\subsubsection{Surface Roughness (Manning’s M)}

The result of increasing surface roughness was to decrease discharge $(Q)$. Jinkang Du et al. [66] also found that runoff on sub-tropical hillslopes in the Jiaokou catchment $\left(259 \mathrm{~km}^{2}\right)$, China, was sensitive to changes in surface roughness $(M)$. Similarly, Sahoo et al. [60] found that flood peaks 
decreased by nearly $1 \mathrm{~m}^{3} / \mathrm{s}$ when $M$ was reduced from 60 to 10 (i.e., smooth to rough) in a mountainous catchment of Hawaii, USA. All of these studies (including this one) were based in steep terrain. It is likely that as slope gradient decreases, surface roughness coefficients would have a greater effect on runoff and water balance outputs.

\subsubsection{Saturated Hydraulic Conductivity $\left(\mathrm{K}_{\mathrm{s}}\right)$}

As infiltration increased under the pasture land cover, a slight increase in discharge $(Q)$ was apparent, but there was little change in $Q$ when infiltration rates were increased in the IVB. Although seemingly counterintuitive, as increased infiltration is generally expected to result in a decrease of $Q$, it is likely that more water was stored within the IVB themselves. Carroll et al. [67], for example, found that infiltration rates were up to 60 times higher under young planted trees than in adjacent pastures in a Welsh grazing landscape. The effect of increased infiltration and enhanced detention storage within the shelterbelts planted across this landscape resulted in a $23 \%$ reduction in runoff [68]. Infiltration rates can also vary with topography, soil depth and soil hydraulic conductivity $[35,69]$. Without knowledge of these parameters from field measurement or a spatial coverage at suitable resolution on which to base simulation models, it is not possible to estimate the degree to which infiltration modifies the partitioning of water to $E T$ and $Q$.

\subsection{Management Implications}

\subsubsection{Benefits of IVB}

The major benefit of applying IVB in a landscape is that they can help to retain more stormwater runoff over greater areas of a hillslope. The changes in soil properties and increased resistance to flow from surface roughness are vital. A significant effect of IVB is the restoration of SAT to levels similar to native woodlands. Plant litter is an important pool of organic matter and nutrients available to be recycled to the soil, which also helps reverse soil compaction [70,71]. The loss of organic matter enhances the effects of compaction on soil that, in turn, reduces the size and number of biopores and the spaces available for water to be retained in a soil [43]. A loss of organic matter and biopores decreases $S A T$ and increases dispersibility when saturated [72], whereas amendments of organic matter can help restore soil water holding capacity [73]. If the species that comprise IVB are biologically diverse, than they also produce a great diversity of litter types which functions to increase the food available to a broad array of soil biota, which also form biopores.

A particularly important function of IVB is the increased surface roughness and detention storage emerging from the accumulation of plant litter. Plant litter and microtopography create rough surfaces that increase surface detention storage, rates of infiltration, hydraulic conductivity and soil water contents [74]. Conversely, if erosion or fire removes the litter layer, there are fewer obstructions to overland flow which reduces soil water-holding capacity, while runoff and sediment removal is increased [75,76]. Together, surface roughness and plant litter attributes increase stormwater retention by slowing the speed of runoff, and increasing detention storage and infiltration. Other ecosystem services that may accrue from IVB are enhanced soil ecosystem processes, water quality, carbon retention and biodiversity conservation $[77,78]$. 


\subsubsection{Limitations of IVB}

The major limitations to installing IVB is the complexity of designing them to match terrain and soil, their cost, competition with pasture/crops, stock trampling, breach failure, drought, fire risk and weeds/feral animals. Any potential functional gain needs to be weighed against these limitations. Trees can compete with crops and pastures [79], although this can be offset by root pruning which has been shown to create higher soil moisture compared to unpruned vegetation [80]. Both fire [81] and heavy grazing can destroy the litter layer and micro-terraces within IVB, although grazing can be controlled with fencing. IVB may pose a potential source area for weeds and feral animals, although due to their compact nature, these should be more easily managed than for more homogenous layouts. Where other functions such as erosion control, shade and shelter, timber products, carbon storage or biodiversity habitat are integrated into IVB, their costs/benefits ratio are likely to increase substantially.

\subsection{Research Limitations and Questions}

Distributed parameter models such as MIKE SHE can simulate the spatial variability in land cover and changes in ecohydrological processes quiet effectively. Whereas the sensitivity analyses provide some guide to the validity of the simulations, model calibration is complex due to the multiple feedbacks between model parameters and their distributed and temporally variable outputs [82]. As rainfall and hillslope hydrological responses are inherently non-linear [83], data must be mapped at hillslope scales in a manner that accurately captures their spatial heterogeneity. However, model development and validation are often constrained by the availability of data and parameter approximations [84].

The temporal resolution of data will also affect the response of the catchment to changes in rainfall intensities, including hydrological responses to land change and configuration $[85,86]$. The simulations presented here were based on a week long period of thunderstorms preceded by a dry period. The reasoning behind this was that regional projections suggest increased drought and up to $40 \%$ greater rainfall intensity by 2030 [4]. This may have affected some hydrological responses, as infiltration capacity and macropore flow connectivity at hillslope scales display strong nonlinear relationships based on antecedent wetness $[87,88]$.

The depth to an impermeable layer is a significant variable determining the proportioning of overland flow in this study, so this factor ideally would need to be accurately mapped across a hillslope. In steeper terrain this would include mapping of rock fragments, as these also affect infiltration [89]. Soil water contents at the upper and lower limits also need careful approximation, as they are likely to be highly heterogeneous at hillslope scales. Along with SAT, data on the type and depth of plant litter is needed to generate estimates of detention storage and surface roughness. Simulations may also be improved by adding bypass flows, such as soil biopores and preferential flow pathways [90]. All of these data, however, are costly to obtain by field sampling.

Further improvements to the design of IVB can be gained through modelling or applied experimentation. This might include different configurations, the use of multiple species with different rooting architecture and water use efficiencies, lower competitiveness with pasture or crop species, and the production of different litter types and biomass which will effect detention storage. Simulating 
alternate configurations would ascertain if the 5\% slope gradient is more important than their orientation in relation to topography. It is likely that for alternate slope gradients, soils and vegetation combinations, the ecohydrological response would show considerable variation. In the case of the IVB modelled in this study, the findings and knowledge generated have been directly applied to optimise a paired catchment study that is currently underway in steep grazing lands of Southeast Queensland, Australia.

\section{Conclusions}

The model results presented in this simulation study underlies the potential for IVB to retain stormwater runoff in high-slope landscapes and under moderate to high intensity rainfall events. The results reveal four key findings:

- At the hillslope scale, simulations predicted that water depth increased beneath IVB but decreased in inter-band spaces. The actual area of hillslope where more than $10 \mathrm{~mm}$ of runoff was retained was increased by $22 \%$ in IVB compared to the pasture land cover, or an $11 \%$ increase in hillslope area external to IVB where extra runoff was retained.

- At the sub-catchment scale, simulations predicted that landscapes with IVB would have $23 \%$ more infiltration and 7\% less discharge than landscapes without these bands. There was a slight lengthening of base flow in the channel.

- Higher SAT levels and greater soil depth were the primary drivers for differences in ecohydrological functioning between pasture and IVB, with secondary functional differences including increased surface roughness, detention storage and infiltration rate.

- Information on the effects of each parameter was used to optimise the selection of instrumentation for a current paired catchment field trial in Southeast Queensland. The findings may also serve as a guide for establishing similar adaptations of IVB in other regions where protection of hillslopes and catchment systems against greater rainfall intensity may be required.

\section{Acknowledgments}

We thank Rick Galbraith (Crows Nest Shire Council) for data support, the Bureau of Meteorology (BOM, Brisbane Office) for pluviograph data, and DHI Water and Environment for supplying the MIKE SHE software and technical support. We acknowledge the Australian Research Council (ARC Linkage Project LP100100356) and the Queensland Department of Science, Information Technology, Innovation and the Arts (DSITIA) for financial and technical support. The University of Queensland's Department of Geography, Planning and Environmental Management also provided operational support. We also acknowledge the innovative water harvesting techniques of Ron Watkins and the late Percival Yeomans. We wish to thank the two anonymous reviewers for LAND who kindly provided a thorough review, which has greatly improved our paper.

\section{Author Contributions}

JGR conceived the design (with ideas from CAM and JAL), JGR preformed the field experiment with support from JNC, JGR wrote the paper with support from the other authors. 


\section{Conflicts of Interest}

The authors declare no conflict of interest.

\section{References}

1. Falkenmark, M.; Rockstrom, J. Balancing Water for Humans and Nature: The New Approach in Ecohydrology; Earthscan Publications: London, UK, 2004.

2. Muller, C.; Malone, T. The Southeast Queensland Flash Flood Event of 9 March 2001; Bureau of Meteorology: Brisbane, QLD, Australia, 2001; p. 54.

3. Pachauri, R.K.; Reisinger, A. Climate Change 2007: Synthesis Report. Contribution of Working Groups I, II and III to the Fourth Assessment Report of the Intergovernmental Panel on Climate Change; IPCC: Geneva, Switzerland, 2007.

4. Abbs, D.; Rafter, T. Climate change and its impact on extreme rainfall in SE Australia. In High Resolution Modelling: Extended Abstracts of the Second CAWCR Modelling Workshop, 25-28 November 2008; Hollis, A.J., Ed.; Centre for Australian Weather and Climate Research: Melbourne, VIC, Australia, 2008; pp. 33-36.

5. Gutiérrez-Jurado, H.A.; Vivoni, E.R.; Harrison, J.B.J.; Guan, H.J. Ecohydrology of root zone water fluxes and soil development in complex semiarid rangelands. Hydrol. Process. 2006, 20, 3289-3316.

6. Boer, M.; Puigdefabregas, J. Effects of spatially structured vegetation patterns on hillslope erosion in a semiarid Mediterranean environment: A simulation study. Earth Surf. Process. Landf. 2005, 30, 149-167.

7. Mitchell, P.B.; Humphreys, G.S. Litter dams and microterraces formed on hillslopes subject to rainwash in the Sydney Basin, Australia. Geoderma 1987, 39, 331-357.

8. Dunkerley, D. Surface tension and friction coefficients in shallow, laminar overland flows through organic litter. Earth Surf. Process. Landf. 2002, 27, 45-58.

9. Duran Zuazo, V.H.; Martinez, J.R.F.; Pleguezuelo, C.R.R.; Martinez Raya, A.; Rodriguez, B.C. Soil-erosion and runoff prevention by plant covers in a mountainous area (SE Spain): Implications for sustainable agriculture. Environmentalist 2006, 26, 309-319.

10. Leguedois, S.; Ellis, T.W.; Hairsine, P.B.; Tongway, D.J. Sediment trapping by a tree belt: processes and consequences for sediment delivery. Hydrol. Process. 2008, 22, 3523-3534.

11. Blanco-Canqui, H.; Gantzer, C.J.; Anderson, S.H. Performance of grass barriers and filter strips under interrill and concentrated flow. J. Environ. Qual. 2006, 35, 1969-1974.

12. Wilson, B.; Lemon, J. Scattered native trees and soils heterogeneity in grazing land on the northern Tablelands of NSW. In Proceedings of the SuperSoil 2004-3rd Australian New Zealand Soils Conference, Sydney, NSW, Australia, 5-9 December 2004.

13. Rao, L.; Zhu, J. Hydrological effects of forest litter and soil in the Simianshan Mountains in Chonging, China. Front. For. China 2007, 2, 157-162.

14. Rachman, A.; Anderson, S.H.; Gantzer, C.J.; Thompson, A.L. Influence of stiff-stemmed grass hedge systems on infiltration. Soil Sci. Soc. Am. J. 2004, 68, 2000-2006.

15. Hook, P.B. Sediment retention in rangeland riparian buffers. J. Environ. Qual. 2003, 32, 1130-1137. 
16. Ellis, T.W.; Leguédois, S.; Hairsine, P.B.; Tongway, D.J. Performance of a tree belt for capturing overland flow from agricultural land-Implications for design. Geophys. Res. Abstr. 2005, 7, 06780.

17. Geddes, N.; Dunkerley, D. The influence of organic litter on the erosive effects of raindrops and of gravity drops released from desert shrubs. CATENA 1999, 36, 303-313.

18. Reynolds, E.R.C.; Thompson, F.B. Forests, Climate and Hydrology: Regional Impacts; United Nations University: Tokyo, Japan, 1988.

19. Danish Hydraulic Institute (DHI). MIKE Zero; DHI: Horsholm, Denmark, 2005.

20. Tongway, D.J.; Ludwig, J.A. Vegetation and soil patterning in semi-arid mulga lands of eastern Australia. Aust. J. Ecol. 1990, 15, 23-34.

21. Abu-Zreig, M.; Rudra, R.P.; Whiteley, H.R.; Lalonde, M.N.; Kaushik, N.K. Phosphorus removal in vegetated filter strips. J. Environ. Qual. 2003, 32, 613-619.

22. Watkins, R. (Payneham Vale, WA, Australia). Personal communication, 2003.

23. Yeomans, P.A. The Keyline Plan; P.A. Yeomans: Sydney, NSW, Australia, 1954.

24. Ryan, J.G. Combining Farmer Decision Making with Systems Models for Restoring Multi-Functional Ecohydrological Systems in Degraded Catchments; Department of Geography and Planning, The University of Queensland: Brisbane, QLD, Australia, 2007; p. 202.

25. Douglas, G.; Palmer, M.; Caitcheon, G.; Orr, P. Identification of sediment sources to Lake Wivenhoe, South-East Queensland, Australia. Mar. Freshw. Res. 2007, 58, 793-810.

26. Geological Survey of Queensland. Queensland Geology; Department of Mines: Brisbane, QLD, Australia, 1975.

27. Jacquier, D.W.; McKenzie, N.J.; Brown, K.L.; Isbell, R.F.; Paine, T.A. The Australian Soil Classification: An Interactive Key, Version 1 ed.; CSIRO Publishing: Collingwood, VIC, Australia, 2003.

28. FAO. World Reference Base for Soil Resources; FAO: Rome, Italy, 1998.

29. Dawen, Y.; Srikantha, H.; Katumi, M. Comparison of different distributed hydrological models for characterization of catchment spatial variability. Hydrol. Process. 2000, 14, 403-416.

30. Jenkins, G.A.; Goonetilleke, A.; Black, R.G. Estimating peak runoff in small catchments. In Proceedings of the 27th Hydrology and Water Resources Symposium, Melbourne, VIC, Australia, 20-23 May 2002.

31. BOM. Pluviograph Data; Bureau of Meteorology: Brisbane, QLD, Australia, 1996.

32. Slavich, P.G.; Hatton, T.J.; Dawes, W.R. The Canopy Growth and Transpiration Model of Waves: Technical Description and Evaluation; CSIRO Land and Water: Wollongbar, NSW, Australia, 1998.

33. Best, A.; Zhang, L.; McMahon, T.; Western, A.; Vertessy, R. A Critical Review of Paired Catchment Studies with Reference to Seasonal Flows and Climatic Variability; CSIRO Land and Water: Canberra, ACT, Australia, 2003.

34. Engman, E.T. Roughness coefficients for routing surface runoff. J. Irrig. Drain. Eng. 1986, 112, 39-53.

35. Eamus, D.; Hatton, T.; Cook, P.; Colvin, C. Ecohydrology: Vegetation Function, Water and Resource Management; CSIRO Publishing: Collingwood, VIC, Australia, 2006; p. 348.

36. McKenzie, N.J.; Jacquier, D.; Isbell, R.F.; Brown, K. Australian Soils and Landscapes: An Illustrated Compendium; CSIRO Publishing: Collingwood, VIC, Australia, 2004. 
37. Loch, R.J.; Espigares, T.; Costantini, A.; Garthe, R.; Bubb, K. Vegetative filter strips to control sediment movement in forest plantations: Validation of a simple model using field data. Aust. J. Soil Res. 1999, 37, 929-946.

38. CSIRO. Australian Soil Resource Information System (ASRIS); CSIRO: Canberra, ACT, Australia, 2008.

39. Harris, P.S.; Biggs, A.J.W.; Stone, B.J. Central Darling Downs Land Management Manual: Field Manual; Queensland Department of Natural Resources: Brisbane, QLD, Australia, 1999.

40. Slattery, B.; Brown, S. Assessment of the Environmental Impact of Fertiliser Applications to Vineyards-A Scoping Study; Grape and Wine Research and Development Corporation: Melbourne, VIC, Australia, 2003.

41. Briggs, D.J.; Smithson, P. Fundamentals of Physical Geography; Rowman \& Littlefield: Totowa, NJ, USA, 1986.

42. Sivapalan, S. Benefits of treating a sandy soil with a crosslinked-type polyacrylamide. Aust. J. Exp. Agric. 2006, 46, 579-584.

43. Yee Yet, J.S.; Silburn, D.M. Deep Drainage Estimates under a Range of Land Uses in the QMDB Using Water Balance Modelling; Queensland Department of Natural Resources \& Mines: Brisbane, QLD, Australia, 2003.

44. Ziegler, A.D.; Tran, L.T.; Giambelluca, T.W.; Sidle, R.C.; Sutherland, R.A.; Nullet, M.A.; Vien, T.D. Effective slope lengths for buffering hillslope surface runoff in fragmented landscapes in northern Vietnam. For. Ecol. Manag. 2006, 224, 104-118.

45. Sneddon, J.; Chapman, T.G. Measurement and analysis of depression storage on a hillslope. Hydrol. Process. 1989, 3, 1-13.

46. Chorley, R.J. The hillslope hydrological cycle. In Hillslope Hydrology; Kirkby, M.J., Ed.; Wiley: Chichester, UK, 1978; pp. 1-42.

47. Bonell, M.; Williams, J. The generation and redistribution of overland flow on a massive oxic soil in a eucalypt woodland within the semi-arid tropics of North Australia. Hydrol. Process. 1986, 1 , 31-46.

48. Yirdaw, E.; Luukkanen, O. Indigenous woody species diversity in Eucalyptus globulus Labill. ssp. globulus plantations in the Ethiopian highlands. Biodivers. Conserv. 2003, 12, 567-582.

49. Gordon, L.; Dunlop, M.; Foran, B. Land cover change and water vapour flows: Learning from Australia. Philos. Trans.: Biol. Sci. 2003, 358, 1973-1984.

50. BOM. Pluviograph data for Lake Cressbrook; Bureau of Meteorology: Brisbane, QLD, Australia, 1999.

51. Ticehurst, J.L.; Croke, B.F.W.; Jakeman, A.J. Model design for the hydrology of tree belt plantations on hillslopes. Math. Comput. Simul. 2005, 69, 188-212.

52. Hewlett, J.D.; Helvey, J.D. Effects of forest clear-felling on the storm hydrograph. Water Resour. Res. 1970, 6, 768-782.

53. Ellis, T.W.; Leguédois, S.; Hairsine, P.B.; Tongway, D.J. Capture of overland flow by a tree belt on a pastured hillslope in south-eastern Australia. Aust. J. Soil Res. 2006, 44, 117-125.

54. Bartley, R.; Roth, C.H.; Ludwig, J.; McJannet, D.; Liedloff, A.; Corfield, J.; Hawdon, A.; Abbott, B. Runoff and erosion from Australia's tropical semi-arid rangelands: Influence of ground cover for differing space and time scales. Hydrol. Process. 2006, 20, 3317. 
55. Ludwig, J.A.; Tongway, D.J.; Marsden, S.G. Stripes, strands or stipples: Modelling the influence of three landscape banding patterns on resource capture and productivity in semi-arid woodlands, Australia. Catena 1999, 37, 257-273.

56. Descheemaeker, K.; Nyssen, J.; Poesen, J.; Raes, V.; Haile, M.; Muys, B.; Deckers, S. Runoff on slopes with restoring vegetation: A case study from the Tigray highlands, Ethiopia. J. Hydrol. 2006, 331, 219-241.

57. Christiaens, K.; Feyen, J. Analysis of uncertainties associated with different methods to determine soil hydraulic properties and their propagation in the distributed hydrological MIKE SHE model. J. Hydrol. 2001, 246, 63-81.

58. Oliver, Y.M.; Smettem, K.R.J. Predicting water balance in a sandy soil: Model sensitivity to the variability of measured saturated and near saturated hydraulic properties. Aust. J. Soil Res. 2005. 43, 87-96.

59. Scherrer, S.; Naef, F.; Faeh, A.O.; Cordery, I. Formation of runoff at the hillslope scale during intense precipitation. Hydrol. Earth Syst. Sci. 2007, 11, 907-922.

60. Sahoo, G.B.; Ray, C.; de Carlo, E.H. Calibration and validation of a physically distributed hydrological model, MIKE SHE, to predict streamflow at high frequency in a flashy mountainous Hawaii stream. J. Hydrol. 2006, 327, 94-109.

61. Fallick, J.B.; Batchelor, W.D.; Tylka, G.L.; Niblack, T.L.; Paz, J.O. Coupling soybean cyst nematode damage to cropgro-soybean. Trans. ASAE 2002, 45, 433-441.

62. Jackson, R.B. The importance of root distributions for hydrology, biogeochemistry, and ecosystem functioning. In Integrating Hydrology, Ecosystem Dynamics, and Biogeochemistry in Complex Landscapes; Tenhunen, J.D., Kabat, P., Eds.; John Wiley and Sons: Chichester, UK, 1999; pp. 219-240.

63. Guevara-Escobar, A.; Gonzalez-Sosa, E.; Ramos-Salinas, M.; Hernandez-Delgado, G.D. Experimental analysis of drainage and water storage of litter layers. Hydrol. Earth Syst. Sci. 2007. $11,1703-1716$.

64. Huber, A.M.; Oyarzun, C.E. Redistribucion de las precipitaciones de un bosque siempreverde del sur de Chile. Turrialba 1992, 42, 192-199.

65. Balazs, A. Interzeptions-verdunstung des waldes im winterhalbjahr als bestimmungsgrobe des nutzbaren wasserdargebots. Beitr. Hydrol. 1982, 4, 79-102.

66. Du, J.; Xie, S.; Xu, Y.; Xu, C.-Y.; Singh, V.P. Development and testing of a simple physically-based distributed rainfall-runoff model for storm runoff simulation in humid forested basins. J. Hydrol. 2007, 336, 334-346.

67. Carroll, Z.L.; Bird, S.B.; Emmett, B.A.; Reynolds, B.; Sinclair, F.L. Can tree shelterbelts on agricultural land reduce flood risk? Soil Use Manag. 2004, 20, 357-359.

68. Jackson, B.M.; Wheater, H.S.; McIntyre, N.R.; Francis, O.J. The impact of upland land management on flooding: Preliminary results from a multi-scale modelling programme. In Proceedings of the BHS 2006 Conference, Durham, UK, 11-13 September 2006; pp. 73-78.

69. Ludwig, J.A.; Tongway, D.J. Clearing savannas for use as rangelands in Queensland: Altered landscapes and water-erosion processes. Rangel. J. 2002, 24, 83-95. 
70. Arvidsson, J. Influence of soil texture and organic matter content on bulk density, air content, compression index and crop yield in field and laboratory compression experiments. Soil Tillage Res. 1998, 49, 159-170.

71. McIvor, J.G. Litterfall from trees in semiarid woodlands of North-East Queensland. Austral Ecol. 2001, 26, 150-155.

72. Rengasamy, P. Clay dispersion. In Soil Physical Measurement and Interpretation for Land Management; McKenzie, N.J., Coghlin, K.J., Cresswell, H.P., Eds.; CSIRO: Melbourne, VIC, Australia, 2002; pp. 200-210.

73. Haynes, R.J.; Naidu, R. Influence of lime, fertilizer and manure applications on soil organic matter content and soil physical conditions: A review. Nutr. Cycl. Agroecosyst. 1998, 51, 123-137.

74. Sidle, R.C. Field observations and process understanding in hydrology: Essential components in scaling. Hydrol. Process. 2006, 20, 1439-1445.

75. Zuazo, V.H.D.; Pleguezuelo, C.R.R. Soil-erosion and runoff prevention by plant covers. A review. Agronomy. Sustain. Dev. 2008, 28, 65-86.

76. Yates, C.J.; Norton, D.A.; Hobbs, R.J. Grazing effects on plant cover, soil and microclimate in fragmented woodlands in south-western Australia: Implications for restoration. Austral Ecol. 2000, 25, 36-47.

77. Ryan, J.G.; McAlpine, C.A.; Ludwig, J.A. Integrated vegetation designs for enhancing water retention and recycling in agroecosystems. Landsc. Ecol. 2010, 25, 1277-1288.

78. Ryan, J.G.; Fyfe, C.T.; McAlpine, C.A. Biomass retention and carbon stocks in integrated vegetation bands: A case study of mixed-age brigalow-eucalypt woodland in southern Queensland, Australia. Rangel. J. 2015, 37, 261-271.

79. McKeon, G.M.; Chilcott, C.; McGrath, W.; Paton, C.; Fraser, G.; Stone, G.S.; Ryan, J.G. Assessing the Value of Trees in Sustainable Grazing Systems; Queensland Department of Natural Resources and Water, Queensland Department of Primary Industries and Fisheries, Environmental Protection Agency: Brisbane, QLD, Australia, 2008; p. 261.

80. Woodall, G.S.; Ward, B.H. Soil water relations, crop production and root pruning of a belt of trees. Agric. Water Manag. 2002, 53, 153-169.

81. Spaeth, K.E.; Pierson, F.B.; Robichaud, P.R.; Moffet, C.A. Hydrology, erosion, plant, and soil relationships after rangeland wildfire. In Conference on Shrubland Dynamics-Fire and Water; US Department of Agriculture, Forest Service Rocky Mountains Forest \& Rangeland Experimental Station: Lubbock, TX, USA, 2004; pp. 62-68.

82. Vázquez, R.F.; Willems, P.; Feyen, J. Improving the predictions of a MIKE SHE catchment-scale application by using a multi-criteria approach. Hydrol. Process. 2008, 22, 2159-2179.

83. Lehmann, P.; Hinz, C.; McGrath, G.; Tromp-van Meerveld, H.J.; McDonnell, J.J. Rainfall threshold for hillslope outflow: An emergent property of flow pathway connectivity. Hydrol. Earth Syst. Sci. 2007, 11, 1047-1063.

84. Beven, K. How far can we go in distributed hydrological modelling? Hydrol. Earth Syst. Sci. 2001, 5, 1-12.

85. Horritt, M.S.; Bates, P.D. Effects of spatial resolution on a raster based model of flood flow. J. Hydrol. 2001, 253, 239-249. 
86. Hessel, R. Effects of grid cell size and time step length on simulation results of the Limburg soil erosion model (LISEM). Hydrol. Process. 2005, 19, 3037-3049.

87. Candela, A.; Noto, L.V.; Aronica, G. Influence of surface roughness in hydrological response of semiarid catchments. J. Hydrol. 2005, 313, 119-131.

88. Coles, N.A.; Sivapalan, M.; Larsen, J.E.; Linnet, P.E.; Fahrner, C.K. Modelling runoff generation on small agricultural catchments: Can real world runoff responses be captured? Hydrol. Process. 1997, 11, 111-136.

89. De Figueiredo, T.; Poesen, J. Effects of surface rock fragment characteristics on interrill runoff and erosion of a silty loam soil. Soil Tillage Res. 1998, 46, 81-95.

90. Van Schaik, N.L.M.B.; Schnabel, S.; Jetten, V.G. The influence of preferential flow on hillslope hydrology in a semi-arid watershed (in the Spanish Dehesas). Hydrol. Process. 2008, 22, 3844-3855.

(C) 2015 by the authors; licensee MDPI, Basel, Switzerland. This article is an open access article distributed under the terms and conditions of the Creative Commons Attribution license (http://creativecommons.org/licenses/by/4.0/). 